\title{
Diversity in Paracoccidioides brasiliensis. The PbGP43 gene as a genetic marker
}

\author{
Rosana Puccia $\cdot$ Juan G. McEwen · Patrícia S. Cisalpino
}

Received: 5 July 2007/ Accepted: 29 August 2007

(C) Springer Science+Business Media B.V. 2007

\begin{abstract}
Paracoccidioides brasiliensis is a temperature-dependent dimorphic fungus and the agent of paracoccidioidomycosis (PCM), which is prevalent in rural workers of Latin American countries. Until a decade ago, most of the studies involving $P$. brasiliensis used clinical isolates, since environmental samples from soil are difficult to obtain. More recently, $P$. brasiliensis has been isolated from infected wild and domestic animals, especially from the nine-banded armadillo Dasypus novemcinctus in Brazil. Over the years, diversity within the species has been observed at several phenotypic levels. The present review will discuss the reports focusing on genetic polymorphism, which culminated with the detection of $P$. brasiliensis phylogenetic species as a result of a multilocus study. Polymorphism in the $\mathrm{PbGP43}$ gene is detailed. This gene encodes fungal glycoprotein gp43, a dominant $P$. brasiliensis antigen largely studied in the last two decades for its
\end{abstract}

R. Puccia $(\bowtie)$

Cell Biology Division, Federal University of São Paulo, UNIFESP, Rua Botucatu, 862, oitavo andar, São Paulo, SP 04023-062, Brazil

e-mail: rpuccia@unifesp.br

J. G. McEwen

Corporación para Investigaciones Biologicas (CIB)

and University of Antioquia, Medellin, Colombia

P. S. Cisalpino

Microbiology Divison, Federal University of Minas

Gerais (UFMG), Belo Horizonte, MG, Brazil importance in diagnosis, immune protection, and adhesive properties to extracellular matrix-associated proteins. Fungal traits associated with genetic groups are discussed.

Keywords Paracoccidioides brasiliensis - Genetic polymorphism $\cdot \mathrm{PbGP} 43$ gene $\cdot$ RAPD .

Chromosomal polymorphism $\cdot$ Phylogenetic species

\section{Introduction}

Paracoccidioides brasiliensis, Histoplasma capsulatum, Blastomyces dermatitidis, Coccidioides immitis and $C$. posadasii constitute a group of thermal dimorphic fungi that cause endemic systemic mycosis. P. brasiliensis is the agent of paracoccidioidomycosis (PCM), which is prevalent in rural workers of Latin American countries. Infection is believed to occur by inhalation of conidia produced by the saprophytic phase of the fungus living in nature [1]. In the lungs, the infectious particles readily transform into the yeast pathogenic form [2] to cause an asymptomatic infection, or active disease in a small percentage of the infected individuals. Until a decade ago, most of the studies involving $P$. brasiliensis used clinical isolates, since environmental samples from soil have been difficult to obtain [3]. More recently, $P$. brasiliensis samples have been isolated from infected wild and domestic animals, especially from the nine-banded armadillo Dasypus novemcinctus in Brazil [1]. 
Over the years, diversity within $P$. brasiliensis has been observed in terms of microscopic [4, 5], macroscopic [6], growth and transition characteristics [7, 8], lipid composition [9, 10], cell wall components [11-13], isoenzyme profiles [14], antigen production [15-17], protein contents [18], and virulence degree [19-22]. The present review will focus on the genetic polymorphism observed in the species, which culminated with the detection of phylogenetic species as a result of a multilocus study [23]. Polymorphism in the PbGP43 gene [24] is detailed. This gene encodes fungal glycoprotein gp43, a dominant $P$. brasiliensis antigen largely studied in the last two decades since its characterization, purification, and production of monoclonal antibodies anti-gp43 [25, 26a, 26b, 27]. The antigen is mostly secreted to the extracellular environment, but it can be found within the cytoplasm and on the cell wall [28]. It bears only one $N$-linked chain [29]. The initial interest in gp43 was concentrated in its diagnostic value, since the protein moiety yields highly specific and sensitive reactions for diagnosis and prognosis of PCM [26a, 30, 31]. However, the importance of gp43 in the host-parasite relationship has later been recognized at the levels of its adhesive properties to extracellular matrix-associated proteins [32, 33] and immune protection. Towards this end, a major T-cell epitope has been mapped in peptide $\mathrm{P}-10$, which is protective to mice and represents a vaccine candidate with immunotherapeutic potential use [34-37].

\section{Chromosomal polymorphism and ploidy}

Early evidences of polymorphism in the number and sizes of chromosomal bands were provided by Montoya et al. [38] and Cano et al. [39], who optimized conditions for separation of $P$. brasiliensis chromosome-sized DNA molecules from clinical isolates using pulsed field gel electrophoresis (PFGE). They found a haploid number of 4 or 5 chromosomal bands, ranging from approximately $2-10 \mathrm{Mb}$. These observations were later confirmed with an increased sample, including environmental isolates [40, 41]. Distinct karyotype profiles showed rather variable banding sizes, characterizing chromosomal length polymorphism. Differences in fluorescence intensity of the ethidium bromide-stained bands suggested that not all bands were present in equimolar amounts and that some could have resulted from co-migration of two or more chromosomes with similar sizes.

The existence of chromosomal polymorphisms made it difficult to compare the banding pattern among $P$. brasiliensis isolates. In order to determine chromosome identity, Feitosa et al. [41] used genetic markers corresponding to nine $P$. brasiliensis genes as probes to hybridize Southern blots of intact chromosomal bands from 12 isolates. Six distinct karyotype profiles and three synteny groups (genetic linkage groups) were identified containing two or three genes each. The adjacent genes $\mathrm{Pb} L O N$ and $\mathrm{PbMDJ}$ [42] mapped to the same chromosomal band $(9.5 \mathrm{Mb}$ in most isolates, 8.7 $\mathrm{Mb}$ in $\mathrm{Pb} 113$ and 6.7 $\mathrm{Mb}$ in Pb339), and so did a putative manosyltransferase gene probe (clone 11), characterizing a synteny group. Another synteny group was CHS1 and 28SrRNA. Adjacent $\mathrm{PbGP43}$ and $\mathrm{PbRanBP}$ also mapped to the same band (9.5 or 4.7), where the $N A G$ probe localized to in 10 isolates. However, in $\mathrm{PbSS}$ and $\mathrm{Pb} 339$ there was a clear dissociation, with $N A G$ being more distant from linked $\mathrm{PbGP43}$ and $\mathrm{PbRanBP}$, suggesting chromosomal rearrangement. The patterns showing Southern blots cross-hybridization of the 10.0 and $3.5 \mathrm{Mb}$ bands strongly suggested the existence of repetitive sequences in the genome of $P$. brasiliensis. No correlation could be established between the karyotype profile and the clinical-epidemiological characteristics of the isolates. Since the linkage groups were generally conserved, in spite of gross differences there is an underlying similarity in the genome organization of $P$. brasiliensis isolates.

The hybridization data [41] provided evidence that translocation and reciprocal translocation might contribute to chromosomal polymorphism in $P$. brasiliensis and that chromosomal rearrangements could provide a means for genetic variation in this organism, as proposed to occur in Candida albicans, and other fungi and eukaryotes [43-45]. The results on the molecular karyotypes of pathogenic fungi demonstrate the overwhelmingly fluidity of chromosome organization among eukaryotes with small genomes, which probably contributes to the maintenance of genome functionality and control of gene expression.

The size of the fungus genome was initially estimated to be in the range of $23-31 \mathrm{Mb}$ by the summation of the molecular weights of chromosome- 
sized DNA molecules resolved by PFGE (or CHEF) [38-41]. However, when the genome size of several isolates was calculated by microfluorometry of 4',6-diamino-2-phenylindole (DAPI)-stained nuclei $[39,41]$ some values $(60 \mathrm{Mb})$ reached twice those estimated by PGFE. Comparison of data generated by both methods indicated the possible existence of haploid, aneuploid and diploid isolates, being therefore inconclusive. On the other hand, both Southern blots of megarestriction fragments with a $\mathrm{PbGP43}$ gene probe [24] and intra-specific polymorphism in the gene sequence [46] suggested diploidy.

Recently, Almeida et al. [47] applied a previously developed flow cytometry (FCM) protocol [48] to determine the genome size per uninucleated $P$. brasiliensis yeast cells and conidia of 10 representative isolates. The genome size calculated by FCM ranged from $26.3 \pm 0.1$ to $35.5 \pm 0.2 \mathrm{Mb}$ per uninucleated yeast cell. The DNA content of conidia from P. brasiliensis ATCC $60855(30.2 \pm 0.8 \mathrm{Mb})$ was similar, possibly excluding the occurrence of ploidy shift during morphogenesis. The ploidy of $P$. brasiliensis isolates was assessed by comparing genome sized by FCM with the previously described average haploid size obtained from electrophoretic karyotyping. The analysis of intra-individual variability of $\mathrm{PbGP} 43$ by sequencing cloned fragments of PCR fragments obtained with proof-reading Taq polymerase indicated that only one allele seems to be present. Overall, the results showed that all analyzed isolates presented a haploid, or at least aneuploid, DNA content and no association was detected between genome size/ploidy and the clinical-epidemiological features of the studied isolates.

\section{Genetic variability in $P$. brasiliensis revealed by RAPD}

In this session, we discuss the works that in the past 12 years have used random amplified polymorphic DNA (RAPD) to recognize $P$. brasiliensis genetic identities among isolates and correlate them with other overlapping fungal features. Details on the correlation with virulence are in a separate item below. RAPD became a popular technique in the 1990s for its simplicity to obtain information about genetic mapping, taxonomy and phylogeny. It is a modification of the polymerase chain reaction (PCR), where genomic fragments are amplified by a single arbitrarily chosen primer, providing a fingerprinting band pattern visible in agarose gels characteristic of similar template DNAs [49].

In $P$. brasiliensis, the first report suggesting the presence of genetically diverse subgroups in P. brasiliensis was released in 1995 [50]. It was a small-scale study with seven clinical isolates from the middle-west part of Brazil and from Equator, where the authors selected five commercially available random primers. They managed to distinguish between two major groups of isolates sharing 35\% of genomic identity. $\mathrm{Pb} 01$ and $\mathrm{Pb} 7455$ composed a separate group II with all primers. The authors later broadened their investigation [51] with the inclusion of other eight isolates and 5 primers, and reached similar results: Group II was composed of Pb01, 7455 and 2514 , which shared only $17 \%$ of genetic similarity with Group I, where subgroups could be identified. While the authors could not appoint any correlation between genetic groups and geographic origin in their studies, they found a relationship between the genetically distant Group II and increased virulence in B10.A mice.

Kurokawa et al. [52] could not find obvious correlation of $P$. brasiliensis virulence with genotypic groups. They analyzed 10 isolates, mostly from the city of Botucatu in São Paulo, Brazil, and used 17 commercial RAPD primers. They obtained a dendrogram with two major clades, where isolates $\mathrm{Bt} 56$ and Bt84 formed a separate group that shared only $56 \%$ of identity with the others. Pb18 and Pb18B6, recently recovered from mice organs, were not $100 \%$ identical, in contrast with the findings from Motta et al. [53]. These authors obtained RAPD profiles with 10 commercial primers and 25 isolates, mostly clinical from the state of São Paulo, Brazil. The resulting dendrogram had two distinct groups, where Bt56, Bt93 and $\mathrm{Pb} 262$ formed a small Group A.

Hahn et al. [54] tested 26 clinical, one armadillo and two soil isolates in their RAPD analysis with 5 primers, which individually generated similar phenograms with a subdivided group I and small group II composed almost exclusively of isolates from Mato Grosso, Brazil. The authors could not correlate genotypic groups with any of the patients' features. However, they observed that all the isolates in group II were from patients who responded well to therapy with trimethoprim-sulfamethoxazole, while other 
three isolates from Mato Grosso, which were assembled in group I, derived from patients who had relapses or were refractory to the sulfa therapy.

Calcagno et al. [55] obtained RAPD profiles from 33 isolates from South American countries using 5 OPG primers. They managed to get full discrimination among isolates with all primers but OPG-18, while OPG-14 alone could discriminate isolates geographically. By using an SSI of 0.63, the isolates were generally grouped according to the country of origin, i.e., Argentina, Brazil, Colombia, Peru, and Venezuela. Geographic discrimination of the same samples was later confirmed using restriction fragment length polymorphism (RFLP), where the restriction enzymes HinfI and HincII produced clear RFLP patterns [56]. Some authors [52, 54] have mentioned that they could not discriminate isolates by their geographical localization using similar primers as Calcagno et al. [55]. However, their results are difficult to compare, because in those investigations either the isolates analyzed were $80 \%$ from Brazil [54] or geographically restricted to São Paulo [52]. Hence, the intrinsic genetic diversity within each group prevailed.

Sano et al. [57] used random primer OPG-19 to study the genetic similarity among different armadillo clones isolated from the same animal, eventually from the same organ, and between armadillo and clinical samples. They studied a total of 83 samples, where 19 were clinical isolates. The resulting dendrogram showed clinical and armadillo samples clustered together in clades I and II, suggesting that the same environmental isolates can infect both humans and armadillos. In addition, they were able to conclude that one armadillo could be infected with genetically distinct isolates, which was later corroborated by $\mathrm{PbGP} 43$ partial sequencing of three samples [58]. Hebeler-Barbosa et al. [59] also found RAPD genetic similarity between $P$. brasiliensis isolates from 10 armadillos and two human PCM patients. In this work, isolates T10B1 (B7) and Bt84 (B25) formed a separate group I and were later found to belong to phylogenetic species 2 [23], as discussed later in this review.

RAPD studies have been useful in the past to determine the existence of genetically distinct $P$. brasiliensis groups, their relationship with geographic distribution and the similarity among clinical, animal and environmental samples; however the information obtained is limited and difficult to compare. Gene polymorphism and multilocus studies, as discussed below, result in more reproducible and informative data.

\section{Genotypic variation in the $\mathrm{PbGP43}$ gene}

$\mathrm{PbGP43}$ was the first gene fully characterized in $P$. brasiliensis [24]. In Pb339, the gene localized to a genomic EcoRI $3.8 \mathrm{~kb}$ cloned fragment, from which a 1,981-pb sequence was initially obtained (GenBank accession number U26160). This fragment contained the $\mathrm{PbGP} 43$ open reading frame (ORF) within 1,329 $\mathrm{bp}$, and part of the $5^{\prime}$ and $3^{\prime}$ intergenic regions $(326$ bp of each). The PbGP43 ORF is composed of two exons separated by one 78-bp intron and the gene apparently has a single copy. ORF translation generates a precursor protein of 416 amino acids bearing a leader peptide of 35 residues, as deduced by $N$-terminal sequencing information of secreted gp43, which predicts alanine as the first amino acid of the extracellular, processed gp43.

We presently know the exact size of the $\mathrm{PbGP43}$ transcript. The preferential transcription start point has been mapped in four isolates by primer extension at position -25 (CA), but two other and less intense sites at -33 (CA) and -35 (TA) have also been detected [60]. The PbGP43 transcription end-point was determined by $3^{\prime}$ RACE in 10 fungal samples, where 11 different poly-A sites, generally PyA, were mapped between positions 1,420 and 1,456 [Morais and Puccia, unpublished results]. Diversity within the poly-A site was detected both intra- and inter-isolates, considering that about ten $3^{\prime}$ RACE generated clones were analyzed for each isolate. Therefore, the $\mathrm{PbGP} 43$ transcript is between 1,367 and 1,413-bp long, which correlates well with the $1.5 \mathrm{~kb}$ originally found in Northern blot [24]. Full sequencing of the EcoRI $3.8-\mathrm{kb}$ insert revealed that the $\mathrm{PbGP} 433^{\prime}$ neighbor is homologous to the gene encoding importin 11 or Ran binding protein 11 (RanBP11), involved in the nucleuscytoplasmatic transport of molecules. The $3^{\prime}$ ends of both genes converge to an intergenic region of about $550 \mathrm{bp}$. $\mathrm{PbGP43}$ and $\mathrm{Pb}$ RanBP-like were found to be linked in 12 different isolates [41], as mentioned earlier.

The PbGP43 sequence revealed by Cisalpino et al. [24] was essential to map the gp43 murine T-cell epitope [34], and to investigate gene polymorphism 
Table 1 Simplified presentation of the $\mathrm{PbGP} 43$ genotypes according to its substitution sites

\begin{tabular}{|c|c|c|c|c|c|c|c|c|c|}
\hline \multicolumn{2}{|c|}{ nucleic acid } & \multicolumn{5}{|c|}{ Genotypes $^{\mathrm{c}}$} & \multicolumn{3}{|c|}{ Aminoacids $^{\mathrm{a}}$} \\
\hline $\begin{array}{c}\text { Substitution } \\
\text { site }^{\mathrm{a}}\end{array}$ & $\begin{array}{c}\text { consensus } \\
\text { nucleotide }\end{array}$ & $\mathbf{A}$ & B & C & D & $\mathbf{E}$ & consensus & position & substitution \\
\hline-259 & $\mathrm{C}$ & & $\mathrm{T}$ & . & . & . & & & \\
\hline-230 & $\mathrm{C}$ & A & . & . & & . & & & \\
\hline-210 & G & & & . & $\mathrm{T}$ & . & & & \\
\hline-209 & $\mathrm{C}$ & & A & . & . & . & & & \\
\hline-120 & $\mathrm{~T}$ & A & . & . & . & . & & & \\
\hline-104 & $\mathrm{C}$ & G & . & . & . & & & & \\
\hline-40 & $\mathrm{C}$ & & & . & . & $\mathrm{T}$ & & & \\
\hline $27^{\mathrm{d}}$ & $\mathrm{C}$ & & $\mathrm{T}$ & $\mathrm{T}$ & . & . & A & 9 & A \\
\hline $268^{\mathrm{e}}$ & G & A & . & . & . & . & D & 90 & $\mathrm{~N}$ \\
\hline $578^{\mathrm{e}}$ & A & G/A & . & . & & . & $\mathrm{H}$ & 167 & $\mathrm{R}$ \\
\hline $589^{\mathrm{e}}$ & A & & & . & G & . & I & 171 & V \\
\hline $617^{\mathrm{e}}$ & G & A & A & A & . & . & $\mathrm{R}$ & 180 & $\mathrm{~K}$ \\
\hline $628^{\circ}$ & A & G & . & . & . & . & I & 184 & $\mathrm{~V}$ \\
\hline 751 & G & A & . & . & . & . & $\mathrm{E}$ & 225 & K \\
\hline 763 & $\mathrm{C}$ & G & . & . & . & . & $\mathrm{H}$ & 229 & D \\
\hline 799 & G & . & & . & $\mathrm{T}$ & $\mathrm{T}$ & A & 241 & S \\
\hline 821 & $\mathrm{C}$ & & T & . & . & . & P & 248 & L \\
\hline 830 & $\mathrm{C}$ & $\mathrm{T}$ & & . & . & . & $T$ & 251 & I \\
\hline 852 & $\mathrm{C}$ & & G & . & . & . & $\mathrm{P}$ & 258 & $\mathrm{P}$ \\
\hline 856 & A & G & . & . & . & . & $\mathrm{T}$ & 260 & A \\
\hline 872 & A & $\mathrm{T}$ & . & . & . & & $\mathrm{Y}$ & 265 & $\mathrm{~F}$ \\
\hline 874 & $\mathrm{C}$ & & & . & . & A & L & 266 & I \\
\hline 912 & $\mathrm{~T}$ & . & $\mathrm{T} / \mathrm{C}$ & . & . & & $\mathrm{F}$ & 278 & $\mathrm{~F}$ \\
\hline 965 & A & & . & . & . & G & D & 296 & G \\
\hline 981 & $\mathrm{C}$ & $\mathrm{T} / \mathrm{c}$ & . & . & . & . & A & 301 & A \\
\hline 1082 & $\mathrm{C}$ & $\mathrm{G} / \mathrm{A} / \mathrm{c}$ & . & . & . & . & $P$ & 335 & $\mathrm{R} / \mathrm{H}$ \\
\hline 1086 & $\mathrm{C}$ & $\mathrm{T}$ & . & . & . & & $S$ & 336 & $S$ \\
\hline 1143 & $\mathrm{C}$ & & & . & . & $\mathrm{C} / \mathrm{T}$ & $S$ & 355 & S \\
\hline 1157 & A & G & . & . & . & . & K & 360 & $\mathrm{R}$ \\
\hline 1166 & $\mathrm{~T}$ & G & . & 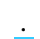 & . & . & L & 363 & $\mathrm{R}$ \\
\hline 1205 & G & & & C & & 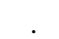 & G & 376 & A \\
\hline
\end{tabular}

Characteristic substitutions for each genotype are colored

${ }^{\text {a }}$ Numbering according to Cisalpino et al. [24]

b Seen in more than half of the isolates [23, Supplementary Table 3]

c Adapted from Hebeler-Barbosa et al. [59]

d Not seen in Morais et al. [46]

e Not analyzed in Matute et al. [23]

[46]. It is worth mentioning that the original sequence, whose position numbering is followed here and in the related literature, has later been updated for mistakes in the GenBank.

The interest to study gene polymorphism originated from the existence of gp43 isoforms observed in the original work characterizing gp43 from Pb339 culture supernatant fluids [25]. Later, Moura-Campos et al. [17] showed that diversity in gp43 isoelectric points (pIs) ocurred both intra- and inter-isolates. The authors described four pI profiles in eight distinct isolates, i.e., A: 6.0, 6.2, 6.6 and 7.0; B: 6.4, 6.8 and 7.2; C: $>8.5$; D: 5.8, 6.2, 6.6. Peculiar profile $\mathrm{C}$ was characteristic of only one sample (Pb1925 or $\mathrm{Pb} 2$ or V2). These pI differences were likely to be due to substitutions in the amino acid sequence, considering 
the lack of ionic groups or acidic sugar moieties in the glycoprotein structure [29].

Sano et al. [58] made the first description of substitution sites in $\mathrm{PbGP43}$. They compared 539 bp from $\mathrm{PbGP} 43$ exon 2 of spleen (D3S1), liver (D3LIV1) and lymph nodes (D3LY1) isolates from the same armadillo and observed substitutions in sites $617,799,821$ and 852 that distinguished the spleen isolate from the others. They also observed that D3S1 caused statistically significant more extensive lung lesions than the other isolates in ddY male mice inoculated intravenously (i.v.) with $P$. brasiliensis.

Morais et al. [46] characterized the $\mathrm{PbGP43}$ polymorphism in a sample composed of one Brazilian armadillo, one Venezuelan soil and 15 clinical isolates from acute and chronic PCM patients mostly from Brazil, but also from Venezuela, Argentina and Peru. The authors compared two cloned PCR fragments from the whole gene (exon 1, intron and exon 2) and later from $326 \mathrm{bp}$ of the promoter region [60]. They found 21 informative substitution sites in the ORF, mostly in exon 2, none in the intron (sites 464-541), and seven in the promoter region, which defined 5-6 genotypes. We are calling informative those sites found in at least two isolates. The maximum-likelihood phylogenetic tree generated by these sequences clearly reflected the presence of specific genetic groups in the species, as already suggested by RAPD. The sequences of isolates $\mathrm{Pb} 2$ (1925 or $\mathrm{V} 2), \mathrm{Pb} 3$ (608 or $\mathrm{B} 26)$ and $\mathrm{Pb} 4$ (1017 or B23) were highly polymorphic (genotype A, Table 1) and phylogenetically distant from the other subgroups. The genetic peculiarity of $\mathrm{Pb} 2, \mathrm{~Pb} 3$ and $\mathrm{Pb} 4$ was also suggested by Southern blot analysis with total DNA digested with $B g l \mathrm{II}$ and hybridized with a $\mathrm{Pb} L O N$ probe [42], which labeled a slower-migrating fragment in these isolates [46].

The existence of $P$. brasiliensis phylogenetic species, however, could only be confirmed later, through a multilocus study from Matute et al. [23], which included $\mathrm{PbGP} 43$ exon 2 and promoter region/ leader sequence. The authors studied DNA extracted from 65 P. brasiliensis isolates from Brazil, Colombia, Paraguay, Peru, Uruguay and Venezuela. They analyzed PCR products directly by automated sequencing and considered both informative and non-informative sites in their analysis. The sample included 13 isolates from Morais et al. [23] and also 12 from Hebeler-Barbosa et al. [59], who used
$\mathrm{PbGP43}$ exon 2 sequence alignments and RAPD to genetically compare isolates from 10 Brazilian armadillos with clinical samples. Table 1 brings a simplified overview of the $\mathrm{PbGP} 43$ genotypic patterns (A-E) based on the informative sites reported by Morais et al. [46], Hebeler-Barbosa et al. [59] and by Matute et al. [23 Supplementary Table 3]. Consensus nucleotides are here defined as those present in more than half of the samples. Note that none of the existing ORFs is consensus, while promoter genotype C sequences (e.g. Pb339) are consensus. Generally, the substitutions resulted in non-synonymous amino acid changes. The characteristics associated with each $\mathrm{PbGP43}$ genotype (Table 1) are listed below. Isoelectric points were calculated for the processed protein [46].

Genotype $A$ (pIs 7.82-8.35): it is the most polymorphic, with up to 15 substitutions in the ORF and three in the promoter. At least 13 substitutions are characteristic of this genotype, specifically $-230(\mathrm{~A})$, -120(A), -104(G), 268(A), 628(G), 751(A), 763(G), 830(T), 856(G), 872(T), 1086(T), 1157(G), 1166(G). So far, six isolates presented this genotype, one from a chronic PCM Venezuelan patient (1925, Pb2 or V2) and five from Brazil, specifically São Paulo (608, Pb3 or $\mathrm{B} 26 ; 1017, \mathrm{~Pb} 4$ or $\mathrm{B} 23 ; \mathrm{Bt} 84$ or $\mathrm{B} 15$; $\mathrm{T} 10 \mathrm{~B} 1$ or $\mathrm{B} 7$ ) and Minas Gerais (Uberlândia or B13). According to a multi-locus analysis discussed later in this review [23], these isolates apparently had an independent evolution and have been classified as phylogenetic species 2 (PS2). The PS2 genealogy was strongly supported by polymorphism in the genes encoding $\mathrm{PbGP} 43$ (both regions), $\alpha$-tubulin and ADP-ribosylation factor.

Genotype B (pI 6,87): it has only been detected in five Venezuelan isolates and two samples from the liver and lymph nodes of same Brazilian armadillo [58], not included in the multi-locus study [23]. It can be distinguished from the others by sites 259(T), -209(A), 821(T) and 852(G). The Venezuelan group could not be considered an isolated phylogenetic species [23].

Genotype $C$ (pI 6,87): it is characteristic of clinical and armadillo isolates from Colombia and of $\mathrm{Pb} 339$. It is characterized by site $1205(\mathrm{C})$ and by having consensus promoter. The Colombian isolates from this group form phylogenetic species 3 (PS3), a geographically restricted group that can be considered an independent lineage by the non-discordance 
criterion [23], which is strongly supported by the $\alpha$ tubulin genealogy.

Genotype $D$ (pI 7,13): it has been detected in a small group of isolates from Peru, Paraguay, Argentina and two from Paraná, Brazil. It is characterized by $-210(\mathrm{~T})$ and $589(\mathrm{G})$.

Genotype $E$ (pI 7,13): it is characteristic of most Brazilian and Argentinean isolates, besides one from Uruguay. Sites $-40(\mathrm{~T}), 874(\mathrm{~A})$, and $965(\mathrm{G})$ can distinguish it. A subgroup of genotype E composed of one Argentinean and five Brazilian isolates is distinguished by site $1143(\mathrm{~T})$.

Isolates that bear $\mathrm{PbGP} 43$ genotypes $\mathrm{B}, \mathrm{D}$ and $\mathrm{E}$ are within the species $\mathrm{S} 1$, a major independent species [23].

While these results justify inter-individual variety in gp43 pI, the origin of intra-individual variation, as reported earlier [17, 25], remains debatable. Morais et al. [46] detected many unique substitution sites (non-informative) and four variations that alone were responsible for intra-individual gp43 pI change. Almeida et al. [48] obtained equal sequences in eight cloned exon 2 fragments from eight isolates. The use of proof-reading polymerase, the limited number of nucleotide analyzed, and the high number of PCR fragments tested by the latter authors are differences to be considered.

\section{Impact of $\mathrm{PbGP43}$ polymorphism at the protein level}

At the protein level, the gp43 sequence belongs to the glycosyl hydrolases family 5 and shares about $50 \%$ of identity with fungal exo- $\beta$-1,3-glucanases, like that from $C$. albicans [24]. Purified gp43 and culture supernatants enriched for the glycoprotein were, however, negative for exo-glucanase activity when tested against laminarin or $p$-nitrophenyl- $\beta$-glucoside [24]. That has been attributed to the lack of a consensus NEP among $\beta-1,3$ as well as $\beta-1$, 6-glucanases [61], which is NKP in gp43 sequences from all isolates analyzed so far [23, 46]. While the involvement of the NEP site in catalysis has been proven in C. albicans [62, 63], in the closely related $H$. capsulatum and B. dematitidis databases (http:// genome.wustl.edu) sequences almost $60 \%$ identical to gp43 have been found where NEP is also present. Hence, in these dimorphs the gp43 homologues possibly code for functional $\beta$-1,3-glucanases. Although the gp43 might be a non-functional glucanase, some traits characteristic of glucanase gene regulation are apparently maintained in the $\mathrm{PbGP43}$ promoter. We are currently studying the $\mathrm{PbGP} 43$ gene regulation and mapping transcription elements in the $5^{\prime}$ untranslated region, from which we presently cloned and sequenced 1,805 bp. We observed that mRNA accumulation sharply decreased 30 min after addition of $1.5 \%$ glucose or cellobiose in the culture medium in three isolates tested [Rocha and Puccia, unpublished observations]. On the other hand, the gene seems to be strikingly regulated by NIT2 transcription elements, present at high numbers in the $5^{\prime}$ non-translated region, considering that mRNA accumulation greatly increased in 3 isolates when exogenously added ammonium sulfate was deprived from the culture medium. Addition of the salt had the opposite effect.

Souza et al. [64] tested purified gp43 isoforms from three isolates using a capture ELISA test and a number of sera from adult and juvenile PCM patients. They found that the reactivity was similar (100\%) among isoforms when the capture monoclonal antibody was MAb8a, but there was a decrease in the number of positive sera from juvenile (56\%) and adult $(71 \%)$ cases reacting with the basic isoform when the capture antibody was MAb17c. This result suggests that some differences in epitope expression might occur depending on the isoform, especially in the most polymorphic basic form. It also indicates that the epitope recognized by MAb17c is common to all isoforms. We have expressed in Pichia pastoris soluble gp43 derived from $\mathrm{PbGP} 43$ genotypes A, D and $\mathrm{E}$ (Table 1). We verified that their reactivity in immunodifusion tests was comparable to that of native protein purified from $\mathrm{Pb} 339$ when 100 PCM sera were tested [Carvalho, Vallejo and Puccia, unpublished results]. We are currently testing more sensitive tests, where differences in reactivity could show using immobilized antigens.

At this point, it is difficult to predict if gp43 isoforms would have an impact in the outcome of PCM. The protective T-cell epitope and vaccine candidate P-10 [34] has a single polymorphic aminoacid at position 184 (Ile or Val), which is out of the epitope core and should not change T-cell recognition. There is one protective antibody detected so far (MAb32), which recognizes a conserved 
epitope encoded in exon 1 [Bruissa-Filho et al., unpublished results]. Further investigation will be necessary to recognize other potentially relevant epitopes and their susceptibility to aminoacid substitution. This is also true for protein putative motifs, such as binding sites for extracellular-associated molecules. Mendes-Giannini et al. [33] have recently tested the capacity of 4 gp43 peptides to inhibit gp43 binding to fibronectin. They managed to inhibit binding to $57 \%$ with a conserved peptide 1 (NLGRDAKRHL), present in the conserved $\mathrm{N}$-terminal. Other peptides (2 and 4) bear polymorphic amino acids, but were weak inhibitors.

\section{Polymorphism in other genes, multilocus studies and phylogenetic species of $\boldsymbol{P}$. brasiliensis}

Several other $P$. brasiliensis genes have been studied for polymorphism, but $\mathrm{PbGP} 43$ exon 2 is the most polymorphic region seen so far. In a multilocus study undertaken by Matute et al. [23], eight regions from five nuclear genes were analyzed in 65 isolates representing 6 endemic areas: promotor-exon 1 and exon 2-4 from chitin synthase (CHS2), exons 2 and 3 from $\beta$-glucan synthase, exons $2-4$ from $\alpha$-tubulin, exons 2-3 from adenyl ribosylation factor $(F K S)$, and promoter-exon 1 and exon 2 from $\mathrm{PbGP43.} \mathrm{Among}$ these gene regions, $F K S$ exons 2 and 3 and $C H S 2$ promotor-exon1 were not relevant due to their low polymorphism. Based on these multilocus genealogies, it was possible to follow the evolutionary lineages and to identify phylogenetic species by means of the criteria of genealogical concordance and non-discordance [65]. This study indicates that $P$. brasiliensis consists of at least three different, previously unrecognized phylogenetic species as follows: S1 (species 1), formed by 38 isolates; PS2 (phylogenetic species 2) enclosing six isolates (five of them from Brazil and one from Venezuela); PS3 (phylogenetic species 3), composed solely by 21 Colombian isolates. The genealogies supporting these clades had both high bootstrap and posterior probabilities values above $70 \%$ and $0,95 \%$, respectively. By means of a similar approach cryptic species have been found in other Onygenalean human pathogenic fungi such as $H$. capsulatum [66] and Coccidioides immitis [67]. The analyses by Matute et al. [23] also provided evidences supporting recombination in nature of at least one of the $P$. brasiliensis species, thus indicating the presence of sexual reproduction. This is reinforced by the presence of teleomorphs in close relatives of $P$. brasiliensis, such as $B$. dermatitidis (Ajellomyces dermatitidis) [68] and $H$. capsulatum (Ajellomyces capsulatum) [69].

Other regions from non-coding DNA have been used for classification purposes, such as the internal transcribed spacer (ITS) regions of the ribosomal DNA complex [59] and microsatellites [70, 71]. ITS1 and ITS2 presented low polymorphism, and most of the sequences were consensus. Microsatellites (simple sequence repeats) are segments of 1-6 nucleotides repeated in tandem. Variations in the number of repeated units result in length polymorphism that can be useful in fungal fingerprinting [72, 73]. In $P$. brasiliensis, microsatellite makers have been selected out of a series of identified repeated sequences and their length polymorphism profiles were originally used to unsuccessfully discriminate between clinical form and fungal genetic trait [70]. On the other hand, Matute et al. [71] were able to discriminate among the three $P$. brasiliensis phylogenetic species by using a set of microsatellite markers, which can be used as typing system. The approach was based on PCR amplification of three selected microsatellites. It is reproducible, easy to assay and acquiescent to high-throughput screening of a large sample of isolates. The system is especially useful for unambiguous discrimination of species S1 and PS2.

Further studies using the CHS2 gene of chitin synthase II, for which the substitution rate was calculated from previous 18S DNA sequences, allowed us to calculate the divergence date of $P$. brasiliensis phylogenetic species. Using two calibration points, the divergence date for PS2 and PS3 was 8.04 mya $(\mathrm{SD}=1.17)$ for the first point, and 8.37 mya $(\mathrm{SD}=0.98)$ for the second point [74].

Ongoing work using partial mitochondrial sequences of five genes from $65 \mathrm{P}$. brasiliensis isolates have revealed that certain genes carry high polymorphism $(C O B, R N 1, R N S)$, thus permitting to draw a more accurate phylogenetic connection between the related species and isolates. Genes such as COX3 and ATP6 have not shown significant variation, and appear highly conserved intraspecies, probably due to the region chosen for the analysis [Salgado and McEween, unpublished results]. 


\section{Genetic groups of $\boldsymbol{P}$. brasiliensis and disease}

In this session, we present the associations made to date between genetic groups discussed earlier and virulence, as tested in animals, or clinical presentation of the disease. Few works have so far reported a positive correlation between genetic groups and disease [51, 60]. On the other hand, the relevance of conclusions and comparisons regarding virulence have to be critically evaluated by the readers, because the authors use different animal models, inoculum sizes, routes of infection, type of analysis, among other possible experimental differences that could lead to different results and conclusions for the same isolate. One important parameter generally disregarded by the researchers is the fungal status at the time of inoculation, i.e., if they have recently been recovered from organs, in-vivo adapted or adapted in vitro, which can lead to attenuation [75, 76]. A single animal passage might not be enough to re-establish full virulence. The use of only one route of infection might also be insufficient to label isolates as highly or weakly virulent. Pb18, a broadly studied isolate, is probably an exception, since it has repeatedly been proven to be highly virulent to different mice strains independently from the route of infection; however it is still susceptible to in vitro attenuation [76]. In regard to clinical PCM features, they are a product of the fungal-host interaction and greatly depend on the host's individual characteristics.

Molinari-Madlum et al. [51] selected six representative isolates from the two RAPD major groups I and II to inoculate sensitive B10.A male mice intraperitoneally (i.p.). Group I isolates showed regressive pattern of infection, with little tissue damage and dissemination, while infection with group II isolates ( $\mathrm{Pb} 01$ and 7455$)$ resulted in intense, progressive and disseminated peritonitis, with extensive tissue damage in the diaphragm and other organs caused by numerous non-organized granuloma. Other reports claimed unsuccessful correlation of RAPD genetic groups with virulence or PCM clinical features [53-55], however they generally relied on medical records and/or literature data about the isolate degrees of virulence. More recently, Kurokawa et al. [52] tested virulence of RAPD genetically distinct isolates and could not correlate the results; however they used outbred swiss mice.
Carvalho et al. [60] used the susceptible B10.A male mouse model to compare the degree of infection caused by $P$. brasiliensis bearing phylogenetically distant $\mathrm{PbGP} 43$ sequences $(\mathrm{Pb} 2, \mathrm{~Pb} 3, \mathrm{~Pb} 4$, phylogenetic group $\mathrm{PS} 2)$ with others $(\mathrm{Pb} 5, \mathrm{~Pb} 8, \mathrm{~Pb} 9, \mathrm{~Pb} 12$, $\mathrm{Pb} 18$, species $\mathrm{S} 1$ ). They compared the rate of fungal recovery from organs (c.f.u.) and histopathology (i) 21 days after i.p. inoculation of in vitro-adapted isolates, (ii) 30 and 60 days after intratraqueal (i.t) infection with organ-recovered isolates and (iii) survival after i.v. infection with organ-recovered and in vivo-adapted isolates. $\mathrm{Pb} 2, \mathrm{~Pb} 3$ and $\mathrm{Pb} 4$ evoked fewer deaths (i.v. infection) and were recovered from the lungs (i.t. infection) at significantly lower c.f.u than the others. Anti-gp43 responses in animals infected with these isolates were richer in IgG2a, IgG2b and IgG3, suggesting a Th1 predominant type of immune response, in contrast with the other sera that were richer in IgG1 and IgA [Carvalho and Puccia, unpublished results]. Furher i.t. infection with in vivo-adapted $\mathrm{Pb} 3, \mathrm{~Pb} 5, \mathrm{~Pb} 12$ and $\mathrm{Pb} 18$ followed for 30, 60 and 120 days showed a similar pattern of anti-gp43 response. Mice infected with $\mathrm{Pb} 3$, whose c.f.u. in the lungs were initially high but declined after 120 days of infection, secreted increasing amounts of IFN- $\gamma$, while IL-10 could only be detected by 30 days of infection. The other animals had progressive infection, decreasing amounts of IFN- $\gamma$, and IL-10 was detected at all time points [Carvalho et al., unpublished results].

These results suggested that PS2 isolates elicit a distinct pattern of host response, which in the B10.A mouse model prevents disease progression. In contrast, PS2 isolate T10F1 (B7), which had been recently isolated from armadillo, was very aggressive in the hamster testicular model [59]. Isolate Bt84 (B15), also in PS2 group, was very virulent in outbred Swiss mice inculated i.v and analyzed 30 days later [52].

If it is true that genetically distinct groups of isolates might have differentially expressed molecules that determine the faith of infection upon contact with the host, some of the features might be related to differential transcription and/or translation regulation. Towards this end, Carvalho et al. [60] observed that the $\mathrm{PbGP} 43$ mRNA accumulation in yeast cells decreased during the first hour of heat shocked at $42^{\circ} \mathrm{C}$ and during the first hours of 
temperature change to $36^{\circ} \mathrm{C}$ for mycelium-to-yeast transition, when compared to $\mathrm{Pb} 18$. The relationship between these differences with polymorphism in the promoter region is still under investigation. The $\mathrm{PbMDJ} 1$ and $\mathrm{Pb} L O N$ genes, which share a $5^{\prime}$ intergenic region containing heat shock and oxidative stress-related transcription elements, respond slower to heat shock in $\mathrm{Pb} 3$ than in $\mathrm{Pb} 18$, while only in $\mathrm{Pb} 18$ does $\mathrm{PbMDJ} 1$ seem to be preferentially expressed in yeast [77]. Sequencing comparison of the intergenic region form $\mathrm{Pb} 3, \mathrm{~Pb} 18, \mathrm{~Pb} 12, \mathrm{~Pb} 5$ and $\mathrm{Pb} 339$ revealed gaps, insertions and substitutions in $\mathrm{Pb} 3$ that might interfere with regulation.

\section{Concluding remarks}

Further work should be oriented to additional characterization of the different $P$. brasiliensis phylogenetic species, in order to look for previously undetected morphological and phenotypic differences, gene regulation, as well as for associated variation in virulence, as previously reported [60]. The possibility of genetic manipulation will be of great value in these studies [78].

Presently, there are two large expression sequence tag (ESTs) databases available for P. brasiliensis. One assembles 4,692 genes from the yeast phase of $\mathrm{Pb} 18$ (S1 species) recently recovered from the spleen of infected mice [79, http://143.107.203.68/pbver2/ default.html]. The other one represents 6,022 expressed genes from the yeast and mycelial phases of in vitro-adapted $\mathrm{Pb} 01$ [80, 81, http://www.biomol. unb.br/Pb]. The complete genome of $P$. brasiliensis will be available in a near future, thanks to the efforts of the Broad Institute with support of the Dimorphic Fungal Genomes Consortium, which is currently developing a comparative genomics project on dimorphic fungal pathogens. The $P$. brasiliensis isolates included in this study are $\mathrm{Pb} 18$, representing major $\mathrm{S} 1$ group and virulence, $\mathrm{Pb} 3$ from phylogenetic species PS2, and $\mathrm{Pb} 01$ as a molecular model. Pb01 alone seems to belong to a phylogenetic group distinct from those previously identified [Carrero et al., unpublished data]. This study will allow the identification, among many other features, of shared and individual genetic determinants of pathogenicity and virulence in dimorphic fungi.
Acknowledgments R. Puccia and P. S. Cisalpino are supported by FAPESP, Capes and CNPq. J. G. McEwen is supported by funds from CODI, University of Antioquia (Sostenibilidad 2005-2006).

\section{References}

1. Bagagli E, Bosco SM, Theodoro RC, Franco M. Phylogenetic and evolutionary aspects of Paracoccidioides brasiliensis reveal a long coexistence with animal hosts that explain several biological features of the pathogen. Infect Genet Evol. 2006;6:344-51.

2. McEwen JG, Bedoya V, Patino MM, Salazar ME, Restrepo A. Experimental murine paracoccidiodomycosis induced by the inhalation of conidia. $\mathrm{J}$ Med Vet Mycol. 1987;25:165-75.

3. Franco M, Bagagli E, Scapolio S, Da Silva LC. A critical analysis of isolation of Paracoccidioides brasiliensis from soil. Med Mycol. 2000;38:185-91.

4. Svidzinski TI, Miranda Neto MH, Santana RG, Fischman O, Colombo AL. Paracoccidioides brasilienses isolates obtained from patients with acute and chronic disease exhibit morphological differences after animal passage. Rev Inst Med Trop Sao Paulo. 1999;41:279-83.

5. Restrepo A. Morphological aspects of Paracoccidioides brasiliensis in lymph nodes: implications for the prolonged latency of paracoccidioidomycosis? Med Mycol. 2000;38: 317-22.

6. Macoris SA, Sugizaki MF, Peracoli MT, Bosco SM, Hebeler-Barbosa F, Simoes LB, Theodoro RC, Trinca LA, Bagagli E. Virulence attenuation and phenotypic variation of Paracoccidioides brasiliensis isolates obtained from armadillos and patients. Mem Inst Oswaldo Cruz. 2006; 101:331-4.

7. Kashino SS, Calich VL, Singer-Vermes LM, Abrahamsohn PA, Burger E. Growth curves, morphology and ultrastructure of ten Paracoccidioides brasiliensis isolates. Mycopathologia. 1987;99:119-28.

8. San Blas G, Padron R, Alamo L, San Blas F. Use of morphology index histograms to quantify populations of the fungal pathogen Paracoccidioides brasiliensis. Microbiology. 1997;143(Pt 1):197-202.

9. Manocha MS, San Blas G, Centeno S. Lipid composition of Paracoccidioides brasiliensis: possible correlation with virulence of different strains. J Gen Microbiol. 1980; 117:147-54.

10. Hamdan JS, de Resende MA, Franzot SP, Cisalpino EO. Biochemical analysis of the methylic antigen of Paracoccidioides brasiliensis. Rev Inst Med Trop Sao Paulo. 1992;34:511-6.

11. San Blas G, San Blas F, Ordaz D, Centeno S, Albornoz MC. Chemical changes in cell wall structure of five strains of Paracoccidioides brasiliensis. Sabouraudia. 1984;22: 255-7.

12. Silva CL, Alves LM, Figueiredo F. Involvement of cell wall glucans in the genesis and persistence of the inflammatory reaction caused by the fungus Paracoccidioides brasiliensis. Microbiology. 1994;140(Pt 5):1189-94. 
13. Crott LS, Lucisano-Valim YM, Silva CL, Barbosa JE. Interactions of $\mathrm{F} 1$ fractions from different strains of Paracoccidioides brasiliensis with human complement and with human neutrophils. Mycopathologia. 1997;140:1927.

14. Svidzinsky TI, Camargo ZP. Isoenzyme profile of Paracoccidioides brasiliensis. J Med Vet Mycol. 1995;33: 281-5.

15. Casotto M, Paris S, Camargo ZP. Antigens of diagnostic value in three isolates of Paracoccidioides brasiliensis. J Med Vet Mycol. 1991;29:243-53.

16. Mendes-Giannini MJ, Toscano E, del Negro GB, Assis CM, Garcia NM. Immunochemical study of a Paracoccidioides brasiliensis polysaccharide-like antigen. J Med Vet Mycol. 1995;33:379-83.

17. Moura-Campos C, Gesztesi JL, Vincentini AP, Lopes JD, Camargo ZP. Expression and isoforms of gp43 in different strains of Paracoccidioides brasiliensis. J Med Vet Mycol. 1995;33:223-7.

18. Salem-Izacc SM, Jesuino RS, Brito WA, Pereira M, Felipe MS, Soares CM. Protein synthesis patterns of Paracoccidiodes brasiliensis isolates in stage-specific forms and during cellular differentiation. J Med Vet Mycol. 1997;35:205-11.

19. Kashino SS, Calich VL, Burger E, Singer-Vermes LM. In vivo and in vitro characteristics of six Paracoccidioides brasiliensis strains. Mycopathologia. 1985;92:173-8.

20. Zacharias D, Ueda A, Moscardi-Bacchi M, Franco M, San Blas G. A comparative histopathological, immunological, and biochemical study of experimental intravenous paracoccidioidomycosis induced in mice by three Paracoccidioides brasiliensis isolates. J Med Vet Mycol. 1986; 24:445-54.

21. Singer-Vermes LM, Burger E, Calich VL, Modesto-Xavier LH, Sakamoto TN, Sugizaki MF, Meira DA, Mendes RP. Pathogenicity and immunogenicity of Paracoccidioides brasiliensis isolates in the human disease and in an experimental murine model. Clin Exp Immunol. 1994; 97:113-9.

22. Hebeler-Barbosa F, Bagagli E. Virulence profiles of ten Paracoccidioides brasiliensis isolates obtained from armadillos (Dasypus novemcinctus). Med Mycol. 2003; 41:89-96.

23. Matute DR, McEwen JG, Puccia R, Montes BA, San Blas G, Bagagli E, Rauscher JT, Restrepo A, Morais F, NinoVega G, Taylor JW. Cryptic speciation and recombination in the fungus Paracoccidioides brasiliensis as revealed by gene genealogies. Mol Biol Evol. 2006;23:65-73.

24. Cisalpino PS, Puccia R, Yamauchi LM, Cano MI, da Silveira JF, Travassos LR. Cloning, characterization, and epitope expression of the major diagnostic antigen of Paracoccidioides brasiliensis. J Biol Chem. 1996;271:4553-60.

25. Puccia R, Schenkman S, Gorin PA, Travassos LR. Exocellular components of Paracoccidioides brasiliensis: identification of a specific antigen. Infect Immun. 1986;53: 199-206.

26. (a) Puccia R, Travassos LR. 43-kilodalton glycoprotein from Paracoccidioides brasiliensis: immunochemical reactions with sera from patients with paracoccidioidomycosis, histoplasmosis, or Jorge Lobo's disease. J Clin
Microbiol. 1991a;29:1610-1615; (b) Puccia R, Travassos LR. The 43-kDa glycoprotein from the human pathogen Paracoccidioides brasiliensis and its deglycosylated form: excretion and susceptibility to proteolysis. Arch Biochem Biophys. 1991b;289:298-302.

27. Puccia R, Travassos LR, Rodrigues EG, Carmona AK, Oliveira MC, Juliano L. Purification of the specific exocellular antigen gp43 from Paracoccidioides brasiliensis. Immunological and proteolytic activities. In: Maresca B, Kobayashi GS, editors. Molecular biology of fungi. New York: Telos Press; 1994. p. 507-15.

28. Straus AH, Freymuller E, Travassos LR, Takahashi HK. Immunochemical and subcellular localization of the 43 kDa glycoprotein antigen of Paracoccidioides brasiliensis with monoclonal antibodies. J Med Vet Mycol. 1996;34: 181-6.

29. Almeida IC, Neville DC, Mehlert A, Treumann A, Ferguson MA, Previato JO, Travassos LR. Structure of the $\mathrm{N}$-linked oligosaccharide of the main diagnostic antigen of the pathogenic fungus Paracoccidioides brasiliensis. Glycobiology. 1996;6:507-515.

30. Giannini MJ, Bueno JP, Shikanai-Yasuda MA, Stolf AM, Masuda A, Amato NV, Ferreira AW. Antibody response to the $43 \mathrm{kDa}$ glycoprotein of Paracoccidioides brasiliensis as a marker for the evaluation of patients under treatment. Am J Trop Med Hyg. 1990;43:200-6.

31. Camargo ZP, Gesztesi JL, Saraiva EC, Taborda CP, Vicentini AP, Lopes JD. Monoclonal antibody capture enzyme immunoassay for detection of Paracoccidioides brasiliensis antibodies in paracoccidioidomycosis. J Clin Microbiol. 1994;32:2377-81.

32. Gesztesi JL, Puccia R, Travassos LR, Vicentini AP, de Moraes JZ, Franco MF, Lopes JD. Monoclonal antibodies against the 43,000 Da glycoprotein from Paracoccidioides brasiliensis modulate laminin-mediated fungal adhesion to epithelial cells and pathogenesis. Hybridoma. 1996;15: 415-22.

33. Mendes-Giannini MJ, Andreotti PF, Vincenzi LR, da Silva JL, Lenzi HL, Benard G, Zancope-Oliveira R, Matos Guedes HL, Soares CP. Binding of extracellular matrix proteins to Paracoccidioides brasiliensis. Microbes Infect. 2006;8:1550-9.

34. Taborda CP, Juliano MA, Puccia R, Franco M, Travassos LR. Mapping of the T-cell epitope in the major 43-kilodalton glycoprotein of Paracoccidioides brasiliensis which induces a Th-1 response protective against fungal infection in BALB/c mice. Infect Immun. 1998;66:786-793.

35. Pinto AR, Puccia R, Diniz SN, Franco MF, Travassos LR. DNA-based vaccination against murine paracoccidioidomycosis using the gp43 gene from Paracoccidioides brasiliensis. Vaccine. 2000;18:3050-8.

36. Iwai LK, Yoshida M, Sidney J, Shikanai-Yasuda MA, Goldberg AC, Juliano MA, Hammer J, Juliano L, Sette A, Kalil J, Travassos LR, Cunha-Neto E. In silico prediction of peptides binding to multiple HLA-DR molecules accurately identifies immunodominant epitopes from gp43 of Paracoccidioides brasiliensis frequently recognized in primary peripheral blood mononuclear cell responses from sensitized individuals. Mol Med. 2003;9:209-19.

37. Marques AF, da Silva MB, Juliano MA, Travassos LR, Taborda CP. Peptide immunization as an adjuvant to 
chemotherapy in mice challenged intratracheally with virulent yeast cells of Paracoccidioides brasiliensis. Antimicrob Agents Chemother. 2006;50:2814-9.

38. Montoya AE, Moreno MN, Restrepo A, McEwen JG. Electrophoretic karyotype of clinical isolates of Paracoccidioides brasiliensis. Fungal Genet Biol. 1997;21:223-7.

39. Cano MI, Cisalpino PS, Galindo I, Ramirez JL, Mortara RA, da Silveira JF. Electrophoretic karyotypes and genome sizing of the pathogenic fungus Paracoccidioides brasiliensis. J Clin Microbiol. 1998;36:742-7.

40. Montoya AE, Alvarez AL, Moreno MN, Restrepo A, McEwen JG. Electrophoretic karyotype of environmental isolates of Paracoccidioides brasiliensis. Med Mycol. 1999;37:219-22.

41. Feitosa LS, Cisalpino PS, Santos MRM, Mortara RA, Barros TF, Morais FV, Puccia R, Silveira JF, Camargo ZP. Chromosomal polymorphism, syntenic relationships, and ploidy in the pathogenic fungus Paracoccidioides brasiliensis. Fungal Genet Biol. 2003;39:60-9.

42. Barros TF, Puccia R. Cloning and characterization of a LON gene homologue from the human pathogen Paracoccidioides brasiliensis. Yeast. 2001;18:981-8.

43. Magee PT. Variations in chromosome size and organization in Candida albicans and Candida stellatoidea. Trends Microbiol. 1993;1:338-42.

44. Magee PT. Analysis of the Candida albicans genome. In Methods in Microbiology. 1998;26:395-415.

45. Chibana H, Beckerman JL, Magee PT. Fine-resolution physical mapping of genomic diversity in Candida albicans. Genome Res. 2000;10:1865-77.

46. Morais FV, Barros TF, Fukada MK, Cisalpino PS, Puccia R. Polymorphism in the gene coding for the immunodominant antigen gp43 from the pathogenic fungus Paracoccidioides brasiliensis. J Clin Microbiol. 2000;38: 3960-6.

47. Almeida AJ, Matute DR, Carmona JA, Martins M, Torres I, McEwen JG, Restrepo A, Leão C, Ludovico P, Rodrigues F. Genome size and ploidy of Paracoccidioides brasiliensis reveals a haploid DNA content: flow cytometry and GP43 sequence. Fungal Genet Biol. 2007;44:25-31.

48. Almeida AJ, Martins M, Carmona JA, Cano LE, Restrepo A, Leao C, Rodrigues F. New insights into the cell cycle profile of Paracoccidioides brasiliensis. Fungal Genet Biol. 2006;43:401-9.

49. Atienzar FA, Jha AN. The random amplified polymorphic DNA (RAPD) assay and related techniques applied to genotoxicity and carcinogenesis studies: a critical review. Mutat Res. 2006;613:76-102.

50. Soares CM, Madlun EE, da Silva SP, Pereira M, Felipe MS. Characterization of Paracoccidioides brasiliensis isolates by random amplified polymorphic DNA analysis. J Clin Microbiol. 1995;33:505-7.

51. Molinari-Madlum EE, Felipe MS, Soares CM. Virulence of Paracoccidioides brasiliensis isolates can be correlated to groups defined by random amplified polymorphic DNA analysis. Med Mycol. 1999;37:269-76.

52. Kurokawa CS, Lopes CR, Sugizaki MF, Kuramae EE, Franco MF, Peracoli MT. Virulence profile of ten Paracoccidioides brasiliensis isolates: association with morphologic and genetic patterns. Rev Inst Med Trop Sao Paulo. 2005;47:257-62.
53. Motta TR, Moreira-Filho CA, Mendes RP, Souza LR, Sugizak MF, Baueb S, Calich VL, Vaz CA. Evaluation of DNA polymorphisms amplified by arbitrary primers (RAPD) as genetically associated elements to differentiate virulent and non-virulent Paracoccidioides brasiliensis isolates. FEMS Immunol Med Microbiol. 2002;33:151-7.

54. Hahn RC, Macedo AM, Fontes CJ, Batista RD, Santos NL, Hamdan JS. Randomly amplified polymorphic DNA as a valuable tool for epidemiological studies of Paracoccidioides brasiliensis. J Clin Microbiol. 2003;41:2849-54.

55. Calcagno AM, Nino-Vega G, San Blas F, San Blas G. Geographic discrimination of Paracoccidioides brasiliensis strains by randomly amplified polymorphic DNA analysis. J Clin Microbiol. 1998;36:1733-6.

56. Nino-Vega GA, Calcagno AM, San Blas G, San Blas F, Gooday GW, Gow NA. RFLP analysis reveals marked geographical isolation between strains of Paracoccidioides brasiliensis. Med Mycol. 2000;38:437-41.

57. Sano A, Tanaka R, Yokoyama K, Franco M, Bagagli E, Montenegro MR, Mikami Y, Miyaji M, Nishimura K. Comparison between human and armadillo Paracoccidioides brasiliensis isolates by random amplified polymorphic DNA analysis. Mycopathologia. 1999;143:165-9.

58. Sano A, Defaveri J, Tanaka R, Yokoyama K, Kurita N, Franco M, Coelho KI, Bagagli E, Montenegro MR, Miyaji M, Nishimura K. Pathogenicities and GP43kDa gene of three Paracoccidioides brasiliensis isolates originated from a nine-banded armadillo (Dasypus novemcinctus). Mycopathologia. 1999;144:61-5.

59. Hebeler-Barbosa F, Morais FV, Montenegro MR, Kuramae EE, Montes B, McEwen JG, Bagagli E, Puccia R. Comparison of the sequences of the internal transcribed spacer regions and $\mathrm{PbGP} 43$ genes of Paracoccidioides brasiliensis from patients and armadillos (Dasypus novemcinctus). J Clin Microbiol. 2003;41:5735-7.

60. Carvalho KC, Ganiko L, Batista WL, Morais FV, Marques ER, Goldman GH, Franco MF, Puccia R. Virulence of Paracoccidioides brasiliensis and gp43 expression in isolates bearing known $\mathrm{PbGP} 43$ genotype. Microbes Infect. 2005; 7:55-65.

61. Martin K, McDougall BM, McIlroy S, Chen J, Seviour RJ. Biochemistry and molecular biology of exocellular fungal beta-(1,3)- and beta-(1,6)-glucanases. FEMS Microbiol Rev. 2007;31:168-92.

62. Cutfield SM, Davies GJ, Murshudov G, Anderson BF, Moody PC, Sullivan PA, Cutfield JF. The structure of the exo-beta-(1,3)-glucanase from Candida albicans in native and bound forms: relationship between a pocket and groove in family 5 glycosyl hydrolases. J Mol Biol. 1999; 294:771-83.

63. Mackenzie LF, Brooke GS, Cutfield JF, Sullivan PA, Withers SG. Identification of Glu-330 as the catalytic nucleophile of Candida albicans exo-beta-(1,3)-glucanase. J Biol Chem. 1997;272:3161-7.

64. Souza MC, Gesztesi JL, Souza AR, Moraes JZ, Lopes JD, Camargo ZP. Differences in reactivity of paracoccidioidomycosis sera with gp43 isoforms. J Med Vet Mycol. 1997;35:13-8.

65. Dettman JR, Taylor JW. Mutation and evolution of microsatellite loci in Neurospora. Genetics. 2004;168: $1231-48$. 
66. Kasuga T, White TJ, Koenig G, McEwen J, Restrepo A, Castaneda E, Da Silva LC, Heins-Vaccari EM, De Freitas RS, Zancope-Oliveira RM, Qin Z, Negroni R, Carter DA, Mikami Y, Tamura M, Taylor ML, Miller GF, Poonwan N, Taylor JW. Phylogeography of the fungal pathogen Histoplasma capsulatum. Mol Ecol. 2003;12:3383-401.

67. Koufopanou V, Burt A, Taylor JW. Concordance of gene genealogies reveals reproductive isolation in the pathogenic fungus Coccidioides immitis. Proc Natl Acad Sci U S A. 1997;94:5478-82.

68. McDonough ES, Lewis AL. Blastomyces dermatitidis: production of the sexual stage. Science. 1967;156:528-9.

69. Kwon-Chung KJ. Emmonsiella capsulata: perfect state of Histoplasma capsulatum. Science. 1972;177:368-9.

70. Nascimento E, Martinez R, Lopes AR, Souza Bernardes LA, Barco CP, Goldman MH, Taylor JW, McEwen JG, Nobrega MP, Nobrega FG, Goldman GH. Detection and selection of microsatellites in the genome of Paracoccidioides brasiliensis as molecular markers for clinical and epidemiological studies. J Clin Microbiol. 2004;42:5007-14.

71. Matute DR, Sepulveda VE, Quesada LM, Goldman GH, Taylor JW, Restrepo A, McEwen JG. Microsatellite analysis of three phylogenetic species of Paracoccidioides brasiliensis. J Clin Microbiol. 2006;44:2153-7.

72. Ellegren H. Microsatellites: simple sequences with complex evolution. Nat Rev Genet. 2004;5:435-45.

73. Bart-Delabesse E, Sarfati J, Debeaupuis JP, van Leeuwen W, van Belkum A, Bretagne S, Latge JP. Comparison of restriction fragment length polymorphism, microsatellite length polymorphism, and random amplification of polymorphic DNA analyses for fingerprinting Aspergillus fumigatus isolates. J Clin Microbiol. 2001;39:2683-6.

74. Matute DR, Torres IP, Salgado-Salazar C, Restrepo A, McEwen JG. Background selection at the chitin synthase II (chs2) locus in Paracoccidioides brasiliensis species complex. Fungal Genet Biol. 2007;44:357-67.

75. Brummer E, Restrepo A, Hanson LH, Stevens DA. Virulence of Paracoccidiodes brasiliensis: the influence of in vitro passage and storage. Mycopathologia. 1990;109:13-7.

76. Kashino SS, Singer-Vermes LM, Calich VL, Burger E. Alterations in the pathogenicity of one Paracoccidioides brasiliensis isolate do not correlative with its in vitro growth. Mycopathologia. 1990;111:173-80.

77. Batista WL, Barros TF, Goldman GH, Morais FV, Puccia R. Identification of transcription elements in the $5^{\prime}$ intergenic region shared by LON and MDJ1 heat shock genes from the human pathogen Paracoccidioides brasiliensis. Evaluation of gene expression. Fungal Genet Biol. 2007;44:347-56.

78. Almeida AJ, Carmona JA, Cunha C, Carvalho A, Rappleye CA, Goldman WE, Hooykaas PJ, Leao C, Ludovico P, Rodrigues F. Towards a molecular genetic system for the pathogenic fungus Paracoccidioides brasiliensis. Fungal Genet Biol. 2007; ahead of print.

79. Goldman GH, dos Reis ME, Duarte R, Souza Bernardes LA, Quiapin AC, Vitorelli PM, Savoldi M, Semighini CP, de Oliveira RC, Nunes LR, Travassos LR, Puccia R, Batista WL, Ferreira LE, Moreira JC, Bogossian AP, Tekaia F, Nobrega MP, Nobrega FG, Goldman MH. Expressed sequence tag analysis of the human pathogen Paracoccidioides brasiliensis yeast phase: identification of putative homologues of Candida albicans virulence and pathogenicity genes. Eukaryot Cell. 2003;2:34-48.

80. Felipe MS, Andrade RV, Petrofeza SS, Maranhao AQ, Torres FA, Albuquerque P, Arraes FB, Arruda M, Azevedo MO, Baptista AJ, Bataus LA, Borges CL, Campos EG, Cruz MR, Daher BS, Dantas A, Ferreira MA, Ghil GV, Jesuino RS, Kyaw CM, Leitao L, Martins CR, Moraes LM, Neves EO, Nicola AM, Alves ES, Parente JA, Pereira M, Pocas-Fonseca MJ, Resende R, Ribeiro BM, Saldanha RR, Santos SC, Silva-Pereira I, Silva MA, Silveira E, Simoes IC, Soares RB, Souza DP, De Souza MT, Andrade EV, Xavier MA, Veiga HP, Venancio EJ, Carvalho MJ, Oliveira AG, Inoue MK, Almeida NF, Walter ME, Soares CM, Brigido MM. Transcriptome characterization of the dimorphic and pathogenic fungus Paracoccidioides brasiliensis by EST analysis. Yeast. 2003;20:263-71.

81. Felipe MS, Andrade RV, Arraes FB, Nicola AM, Maranhao AQ, Torres FA, Silva-Pereira I, Pocas-Fonseca MJ, Campos EG, Moraes LM, Andrade PA, Tavares AH, Silva SS, Kyaw CM, Souza DP, Pereira M, Jesuino RS, Andrade EV, Parente JA, Oliveira GS, Barbosa MS, Martins NF, Fachin AL, Cardoso RS, Passos GA, Almeida NF, Walter ME, Soares CM, Carvalho MJ, Brigido MM. Transcriptional profiles of the human pathogenic fungus Paracoccidioides brasiliensis in mycelium and yeast cells. J Biol Chem. 2005;280:24706-14. 